\title{
Ash Whitefly, Siphoninus phillyreae (Haliday) (Insecta: Homoptera: Aleyrodidae: Aleyrodinae) ${ }^{1}$
}

\section{Ru Nguyen and Avas B. Hamon ${ }^{2}$ \\ Introduction}

Ash whitefly, Siphoninus phillyreae, was described as Aleyrodes phillyreae by Haliday (1835), on Phillyrea latifolia collected in Dublin, Ireland. It has several synonyms listed in Mound and Halsey (1978). In the United States, S. phillyreae was first collected in Los Angeles County, California in 1988, and has since spread to Kern, Orange, Riverside, Sacramento, San Bernardino, San Diego, Santa Barbara, Santa Clara, Stanislaus, Tulare and Ventura counties. Most ash whiteflies in California were found on pomegranate, ash tree, pear, apple, loquat and citrus. It causes severe damage to pear and apple in Europe. Heavy infestations caused leaf wilt, early leaf drop and smaller fruit (Bellows et al. 1990). If this whitefly is introduced into Florida we expect it to become a pest of ornamental plants and possibly other crops.

\section{Description}

On first observation the pupal case will appear similar to the white male armor of a snow scale (Figure 1). Closer observation with a hand lens will reveal a whitefly pupal case with two longitudinal tufts of white wax. The vasiform orifice is surrounded by dark brown derm, with the anal area appearing as a dark brown spot. Lateral areas of the pupal case are light beige. Depending on the age, lesser or greater amounts of white wax will be present (Figure 2). The dorsal surface has 40 to 50 long glassy tubercles similar to the cornicles found on aphids. These tubercular structures produce a droplet of glassy wax and this gives the pupal case an unusual appearance. The longitudinal white tufts of wax obscure some glassy tubercles (R.J. Gill, personal communication). The pupal case size is 0.8 to $1.0 \mathrm{~mm}$ long by 0.55 to $0.7 \mathrm{~mm}$ wide (Mound 1966). The adult (Figure 3) appears much like a typical whitefly with a light dusting of white wax.

\section{Distribution}

Siphoninus phillyreae, a Palaearctic species, is found in several countries, including: Austria, Cameroon, Corsica, Czechoslovakia, Cyprus, Egypt, England, Ethiopia, France, Germany, India, Iran, Hungary, Ireland, Israel, Italy, Libya, Morocco, Pakistan, Poland, Romania, Saudi Arabia, Spain,

1. This document is EENY-147, one of a series of Featured Creatures from the Entomology and Nematology Department, Florida Cooperative Extension Service, Institute of Food and Agricultural Sciences, University of Florida. Published: August 2000. Revised: November 2002. This document is also available on Featured Creatures Website at http://creatures.ifas.ufl.edu. Please visit the EDIS Website at http://edis.ifas.ufl.edu. Additional information on these organisms, including many color photographs, is available at the Entomology and Nematology Department website at http://entnemdept.ifas.ufl.edu/.

2. Ru Nguyen and Avas B. Hamon, Florida Department of Agriculture and Consumer Services, Division of Plant Industry, Gainesville, FL.

The Institute of Food and Agricultural Sciences is an equal opportunity/affirmative action employer authorized to provide research, educational information and other services only to individuals and institutions that function without regard to race, color, sex, age, handicap, or national origin. For information on obtaining other extension publications, contact your county Cooperative Extension Service office. Florida Cooperative Extension Service/Institute of Food and Agricultural Sciences/University of Florida/Christine Taylor Waddill, Dean. 


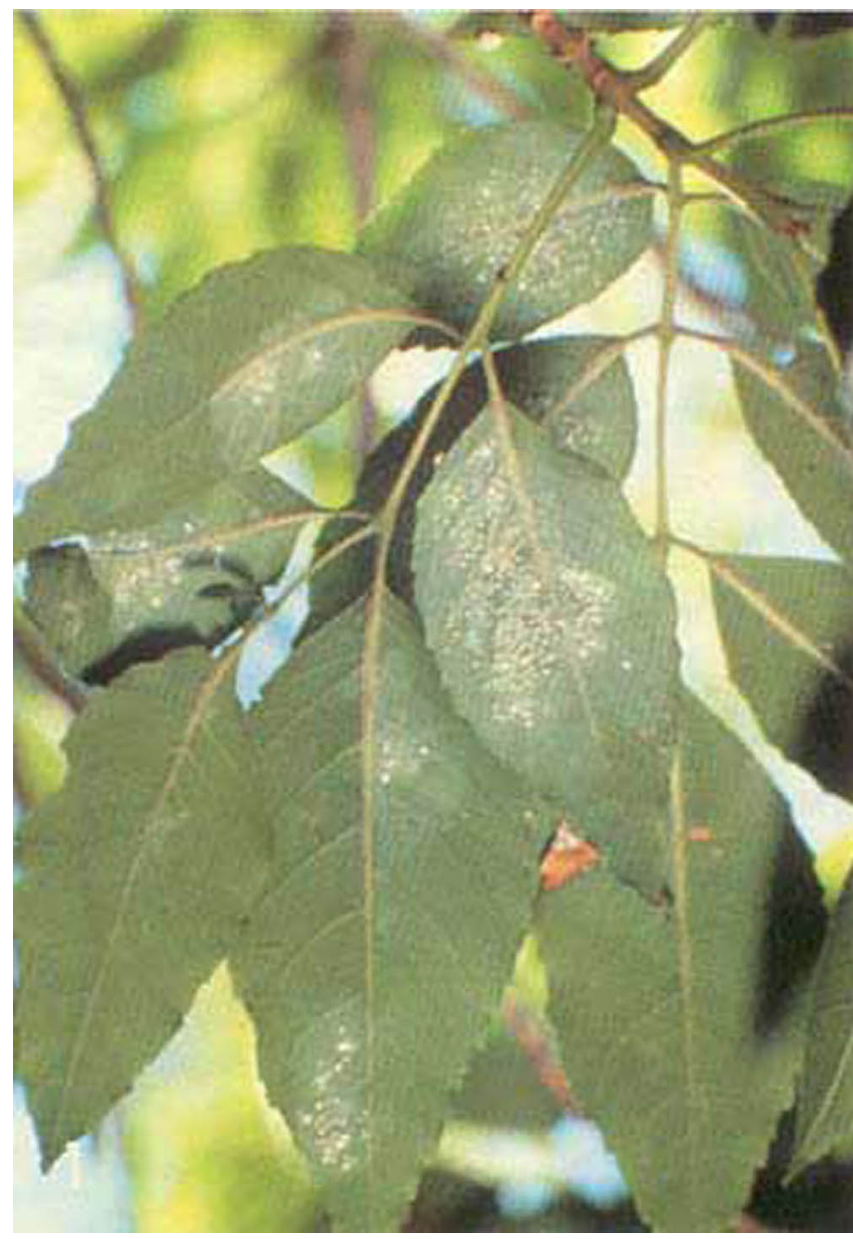

Figure 1. Pupal cases and nymphs of the ash whitefly, Siphoninus phillyreae (Haliday), on host plant. Credits: C.H. Webb, Division of Plant Industry

Sudan, Syria, Switzerland, Yugoslavia, and United States (Arizona, California and Nevada) (Mound and Halsey 1978, Bellows et al. 1990, and Raymond Gill, personal communication, Chris Baptista, personal communication).

\section{Host Plants}

Siphoninus phillyreae is a polyphagous species and is found on several plant families, (modified from Bellows et al. 1990) including:

- Bignoniaceae: Catalpa X chilopsis, catalpa hybrid

- Leguminosae: Afzelia sp., pod mahogany; Cercis occidentalis, western redbud; $C$. siliquastrum, Judas tree

- Lythraceae: Lagerstroemia indica, crape myrtle

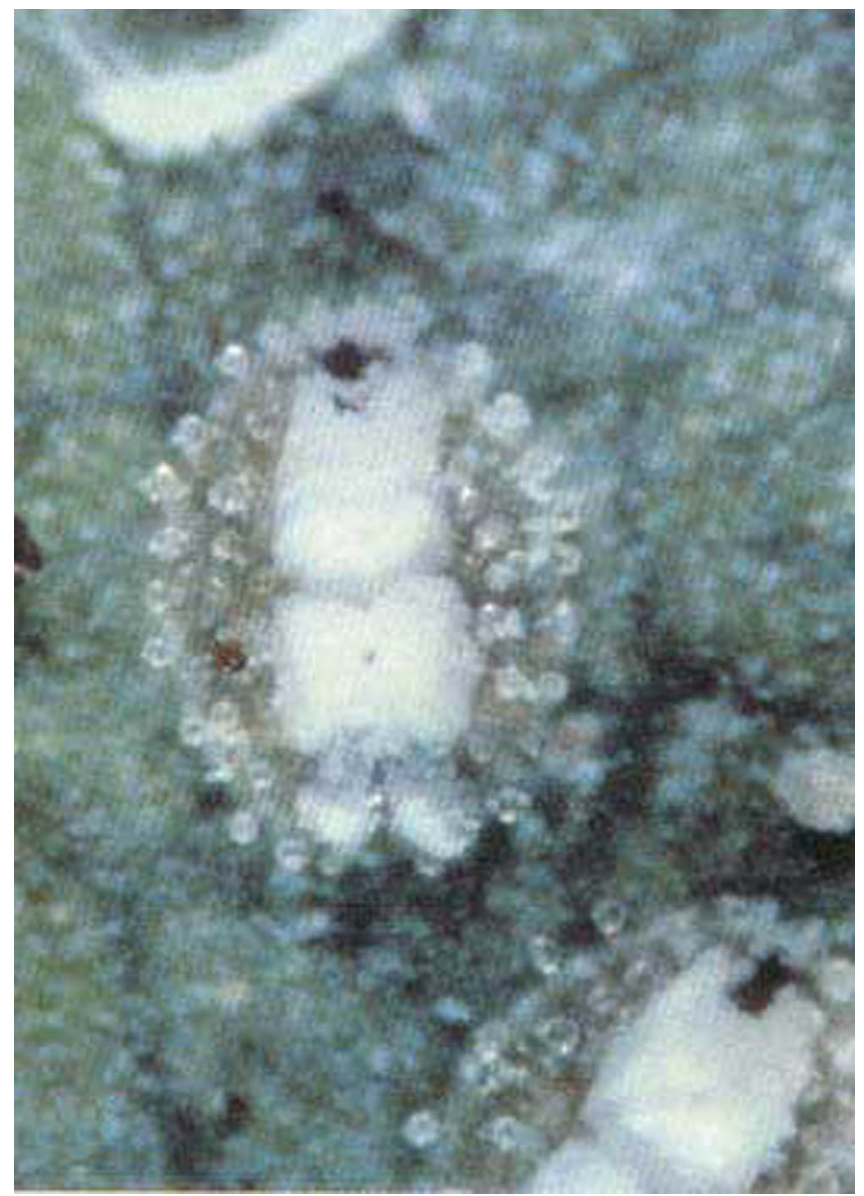

Figure 2. Pupal case of the ash whitefly, Siphoninus phillyreae (Haliday), showing glassy wax droplets. Credits: C.H. Webb, Division of Plant Industry

- Magnoliaceae: Liriodendron tulipifera, tulip tree; Magnolia stellata, star magnolia

- Oleaceae: Fraxinus excelsior, European ash; F. latifolia, Oregon ash; $F$. ornus, flowering ash; $F$. syriaca, Serian ash; $F$. uhdei, Shamel ash; $F$. uhdei 'Tomlinson', Tomlinson ash; F. velutina 'Modesto', Modesto ash; F. velutina var. glabra, Arizona ash; F. velutina var. coriacea, western ash; Ligustrum spp., privets; Olea africana (=Olea chrysophylla), wild olive; O. europaea, common olive; Phillyrea latifolia (=Phillyrea media), a phillyrea; Syringa X hyacinthiflora, a common lilac; $S$. laciniata, cut-leaf lilac; $S$. vulgaris, common lilac

- Punicaceae: Punica granatum, pomegranate

- Rhamnaceae: Rhamnus alaternus, buckthorn; Ziziphus spina-christi, crown of thorns 


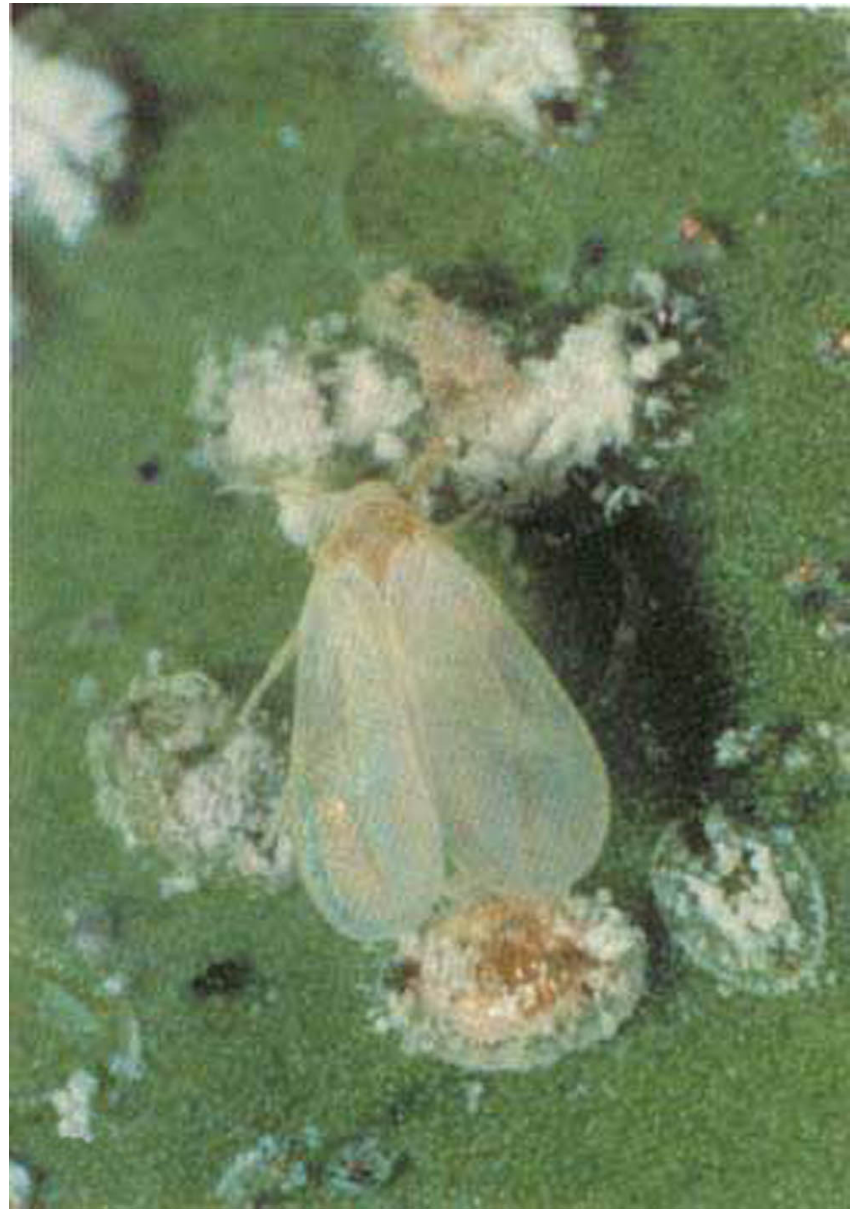

Figure 3. Adult ash whitefly, Siphoninus phillyreae (Haliday). Credits: C.H. Webb, Division of Plant Industry

- Rosaceae: Amelanchier denticulata, serviceberry; Chaenomeles $X$ speciosa, flowering quince; Crataegus mollis, hawthorn; $C$. monogyna, English hawthorn; $C$. laevigata $(=C$. oxyacantha), hawthorn; Cydonia oblonga, quince; Eriobotrya deflexa, golden loquat; Heteromeles arbutifolia, California Christmas berry; Malus domestica, apple; M. floribunda, Japanese flowering crab; $M$. fusca, Oregon crabapple; Malus 'Hopa', a crabapple; Malus 'Red Jade', a crabapple; Malus X scheideckeri, Scheidecker crabapple; Mespilus sp., mespilus; Prunus armeniaca, apricot; $P$. X blireiana, blue plum hybrid; $P$. persica, peach; $P$. salicina, Santa Rosa plum; P. virginiana var. melanocarpa, choke cherry; Pyracantha sp., pyracantha; Pyrus calleryana, ornamental pear; P. communis (=P. sativa), pear; P. kawakamii, flowering pear; $P$. pyrifolia, Japanese sand pear
- Rubiaceae: Cephalanthus occidentalis var. californicus, buttonbush

- Rutaceae: Citrus sp., tangerine; C. limon, lemon; $C$. sinensis, navel orange; $C$. sinensis, Valencia orange; Fortunella sp., kumquat.

\section{Natural Enemies}

Ash whitefly has the potential to become a serious pest in new environs. However, it has several natural enemies that can control its populations to under economic thresholds. These natural enemies include (Mound and Halsey 1978; Bellows et al. 1990; Viggiani and Mazzone 1980; Viggiani and Battaglia 1983):

Predators: Clitostethus arcuatus (Rossi), Menochilus sp., and Scymnus pallidivestis Mulsant.

Parasites: Coccophagus eleaphilus Silvestri, Encarsia gautieri (Mercet), Encarsia inaron (Walker), Encarsia partenopea Masi, Encarsia siphonini Silvestri, Encarsia pseudopartenopea Viggiani and Mazzone; Eretmocerus siphonini Viggiani and Battaglia, and Eretmocerus corni Haldeman.

The California Department of Food and Agriculture has imported Encarsia sp. from Israel and Italy, and the coccinellid beetle Clitostethus arcuatus for the control of ash whitefly in California (Bellows et al. 1990).

\section{Selected References}

- Bellows, T.S., T.D. Paine, K.Y. Arakawa, C. Meisenbacher, P. Leddy, and J. Kabashimo. 1990. Biological control sought for ash whitefly. California Agriculture 44 (1): 4-6.

- Evans, G.A. and A.B. Hamon. (5 November 2002). Whitefly taxonomic and ecological Web site: an on-line interactive catalog of the whiteflies (Hemiptera: Aleyrodidae) of the world and their parasites and predators. http://www.fsca-dpi.org/homoptera_hemiptera/ Whitefly/whitefly_catalog.htm (13 November 2002). 
- Haliday, A.H. 1835. Aleyrodes phillyreae.

Entomol. Mag. 2: 119-120.

- Mound, L.A. 1966. A revision of the British Aleyrodidae (Hemiptera: Homoptera). Bull. Br. Mus. Nat. Hist., Ent. 17 (9): 419-420.

- Mound, L.A., and S.H. Halsey. 1978. Whitefly of the world. A systematic catalogue of the Aleyrodidae (Homoptera) with host plant and natural enemy data. British Mus. (Nat. Hist.) and John Wiley and Sons, New York, NY. p. 192-193.

- Viggiani, G., and P. Mazzone. 1980. Encarsia pseudopartenopea n.sp., parassita di Siphoninus phillyreae (Haliday) (Hom. Aleyrodidae). Bollettino el Laboratorio di Entomologia Agraria 'Filippo Silvestri' 37: 9-12.

- Viggiani, G., and D. Battaglia. 1983. Le specie italiane del genere Eretmocerus Hald. (Hymenoptera: Aphelinidae). Bolletino del Laboratorio di Entomologia Agraria 'Filippo Silvestri' 40: 97-101. 